\title{
SHORTAGE OF WATER IN TEESTA RIVER BASIN AND ITS IMPACT ON CROP PRODUCTION IN NORTHERN BANGLADESH
}

\author{
M.L. Raihan", M.A. Sarker and M.A.M. Miah \\ Department of Agricultural Extension Education, Bangladesh Agricultural University \\ Mymensingh, Bangladesh
}

\begin{abstract}
The objectives of the study were to (i) assess the extent of water shortage in the downstream of Teesta River Basin (TRB) areas; (ii) explore the problems associated with crop production due to water shortage in TRB areas and (iii) examine the impact of water shortage on crop production in TRB areas. The study was conducted in four villages under Nilphmari district during April, 2015. By secondary data analysis and farmers' perception it was clear that water flow and discharge of Teesta river was decreasing significantly during the last 15 years. The major impact was the dramatic increase in costs of irrigation of major crops and ultimately rise in the costs of production and less profit from farming. All of the farmers $(100 \%)$ opined that the irrigation costs of major crops have been increasing due to shortage of water. The cultivation of LWRC due to water shortage was also a major impact of water shortage on crop production. Farmers were concentrating more on cultivating maize, tobacco, wheat, different types of vegetables etc. compared to rice particularly in dry season. Different types of problems like increased amount of heavy metal in crop land due to continuous uplifting of ground water, decrease soil fertility, increase pests and diseases to crops, fallowing of high and medium high land, increase of fertilizer and pesticide costs etc. were affecting farmers severely in crop production.
\end{abstract}

Keywords: Water shortage impact, crop production, Teesta river basin

\section{INTRODUCTION}

Bangladesh is a very small agrarian country with 142.32 million people (BBS, 2011). In the recent time agriculture sector of the country is facing many challenges especially due to consequences of climate change and manmade causes. The Teesta river being a major source of ground water recharge in North- Western part of Bangladesh and was used for irrigation purposes for long time. Teesta Barrage

*Corresponding author e-mail: masarker@bau.edu.bd 
Project (TBP), which is located at the Teesta Flood Plains (TFP) at Dalia point in Nilphamari district, has been a major source of surface water irrigation in NorthWestern part of Bangladesh by gravity flow since 1990. Reduction of dry season flow of Teesta has significant consequences on its ecosystem services. It is through this process, the mighty Teesta has been tamed as it lost its might and its flow has reduced to only a few cusecs in dry periods (Haque et al., 2014). For the last several years these areas are facing serious water related difficulties like river bed siltation, low water flow, fresh and water bodies becoming dry etc. (The Daily Star, 16-042011). Of the 147 billion cubic meters required in the country during dry season, only 90 billion cubic meters is available. This $40 \%$ deficit leads to drought in some regions (Mbugua and Snijders, 2011). People face many problems in dry season getting water in tube wells and in irrigation canals. Therefore people rely on deep tube well or shallow tube well. Not all farmers have access to these means. Because of water shortage crop production is decreasing, causing less income for farmers and less availability of food for the local communities and serious impact on annual crop production (Mullick et al., 2011). People are now suffering due to the rising costs of lifting water, thereby increasing cost of irrigation and crop production (Haque et al., 2014). The price for installation of shallow machine is much higher compared to past years. In some high land areas, the groundwater level is so deep that sinking of shallow machine is too costly, especially in some areas of Nilphamari Sadar and Joldhaka upazila (Mbugua and Snijders, 2011). Again, farmers of these area are now changing their cropping pattern (larger area coverage by maize and tobacco) without considering ecological effect and food security and moving to other professions other than farming (Islam and Higano, 2011). Arsenic is a great problem in the study area and this problem worsening continually due to the injudicious uplifting of ground water (Rahman, 2005). In view of the above background and facts, the present study aimed at gathering information regarding the following questions:

- What extent the water shortage is found in Teesta River Basin?

- What extent of problems confronted by the farmers engaged in crop production due to shortage of water?

- What extent the impact of water shortage on crop production?

\section{MATERIALS AND METHODS}

This study employed both quantitative and qualitative research approaches in order to get a comprehensive view of the shortage of water and its impact on crop production. The study were conducted in four villages namely Dubachuri Gondeyapara, Hajipara, Nakbakta and Kalikaganj under Ramnagar, Laxmichap, Saulmari and Daoabari unions respectively in Nilphamari Sadar and Joldhaka upazila under Nilphmari district. Nilphamari district was selected purposively as it is one of the most affected districts due to water shortage in Teesta river of Bangladesh (Mbugua and Snijders, 2011). About 1250 farm families live in each village of Ramnagar, Laxmichap, 
Daoabari and Soalmari unions of Nilphamari Sadar and Joldhaka upazilas (BBS, 2011). List of farmers were taken from respective Sub-Assistant Agriculture Officers (SAAOs) of each village and farmers were randomly taken as respondents. The target population was 300 , which was taken randomly from four unions.

Out of these 300 populations, 25 percent populations were selected from each village as sample. Hence, the sample size was 75 . In order to collect relevant data for the study, a structured interview schedule was carefully prepared keeping the objectives in mind. The interview schedule was pre-tested with 20 farmers by the researcher. A sub-sample of 20 farmers was selected for FGD. The dependent variable of the study was the impact of water shortage on crop production and the explanatory variables were eight (8) selected socio-economic characteristics. Causes of water shortage were measured by two dimensions such as change in climate and increase in withdrawal of water from upstream. The impact on crop production was measured on the basis of the extent of changes occurred in two (2) selected dimensions of crop production as a result of water shortage in Teesta river. i) Changes of crop choices due to water shortage and ii) Changes in irrigation cost of major crops due to water shortage. The respondents were asked to mention their common cropping pattern or crop choices pattern they had been practicing over the years in three common seasons, namely, Rabi (16 October-15 March), Kharif-1 (16 March-30 June) and Kharif-2 (1 July-15 October). The separate information regarding cropping pattern of the respondents were written under "before 2000" and "at present". The respondents were asked to mention their irrigation costs (in '000' taka) for major crops like rice (Boro and Aman), wheat, maize, tobacco and potato per hectare area in "before 2000" and "at present". The changes in average costs were computed and compared using "T-test". Eight characteristics of the farmers were selected as independent variables of the study. A Problem Facing Index (PFI) for each 10 selected problems was computed by using the following formula:

$\mathrm{PFI}=\left(\mathrm{P}_{\mathrm{h}} \times 3\right)+\left(\mathrm{P}_{\mathrm{m}} \times 2\right)+\left(\mathrm{P}_{1} \times 1\right)+\left(\mathrm{P}_{\mathrm{n}} \times 0\right)$

Where,

$\mathrm{P}_{\mathrm{h}}=$ Number of responses indicating high problem

$\mathrm{P}_{\mathrm{m}}=$ Number of responses indicating medium problem

$\mathrm{P}_{1=}$ Number of responses indicating low problem

$\mathrm{P}_{\mathrm{n}}=$ Number of responses indicating no problem

Problem Facing Index (PFI) for any one of the selected problem could range from 0 to 225 , where, 0 indicated no problem facing and 225 indicated highest problem facing. 


\section{RESULTS AND DISCUSSIONS}

\section{Selected characteristics of the farmers}

Table 1. Summary statement showing categories and salient features of the selected characteristics of the farmers $(\mathrm{N}=75)$

\begin{tabular}{|c|c|c|c|c|c|c|}
\hline \multirow{2}{*}{$\begin{array}{c}\text { Selected } \\
\text { characteristics }\end{array}$} & \multirow{2}{*}{$\begin{array}{c}\text { Measuring } \\
\text { unit }\end{array}$} & \multirow[t]{2}{*}{ Categories } & \multicolumn{2}{|c|}{ Respondents } & \multirow[t]{2}{*}{ Mean } & \multirow[t]{2}{*}{ SD } \\
\hline & & & No & $\%$ & & \\
\hline \multirow{4}{*}{ Age } & \multirow{4}{*}{ Year } & Young (18-35) & 18 & 24 & \multirow{3}{*}{46.89} & \multirow{3}{*}{10.91} \\
\hline & & Middle (36-55) & 37 & 49.3 & & \\
\hline & & Old $(>55)$ & 20 & 26.7 & & \\
\hline & & Illiterate $(0)$ & 20 & 26.7 & \multirow{4}{*}{4.84} & \multirow{4}{*}{4.35} \\
\hline \multirow{3}{*}{$\begin{array}{l}\text { Level of } \\
\text { education }\end{array}$} & \multirow{3}{*}{$\begin{array}{l}\text { Years of } \\
\text { schooling }\end{array}$} & Primary (1-5) & 27 & 36 & & \\
\hline & & Secondary $(6-10)$ & 20 & 26.7 & & \\
\hline & & Higher secondary $(>12)$ & 8 & 10.6 & & \\
\hline \multirow{5}{*}{ Farm size } & \multirow{5}{*}{ Hectare } & Landless (0.002-0.02) & 0 & 0 & \multirow{5}{*}{1.18} & \multirow{5}{*}{0.62} \\
\hline & & Marginal (0.021-0.2) & 0 & 0 & & \\
\hline & & Small (0.21-0.99) & 41 & 54.7 & & \\
\hline & & Medium (1.0-3.0) & 33 & 44 & & \\
\hline & & Large (> 3.0) & 1 & 1.3 & & \\
\hline \multirow{3}{*}{$\begin{array}{c}\text { Annual family } \\
\text { income }\end{array}$} & \multirow{3}{*}{$\begin{array}{l}\text { Thousand } \\
\text { taka }\end{array}$} & Low (up to 96) & 43 & 57.3 & \multirow{3}{*}{97.37} & \multirow{3}{*}{23.69} \\
\hline & & Medium (97-130) & 26 & 34.7 & & \\
\hline & & High $(>130)$ & 6 & 8 & & \\
\hline \multirow{4}{*}{$\begin{array}{c}\text { Agricultural } \\
\text { training } \\
\text { experience }\end{array}$} & \multirow{4}{*}{ Days } & No training $(0)$ & 21 & 28 & \multirow[b]{3}{*}{4.04} & \multirow{4}{*}{3.99} \\
\hline & & Short duration (1-7) & 34 & 45.3 & & \\
\hline & & Medium duration (8-15) & 20 & 26.7 & & \\
\hline & & Long duration $(>15)$ & 0 & 0 & & \\
\hline \multirow{3}{*}{$\begin{array}{r}\text { Extension } \\
\text { media } \\
\text { contact }\end{array}$} & \multirow{3}{*}{ Scale } & Low contact (up to 12 ) & 33 & 44 & \multirow{3}{*}{18.29} & \multirow{3}{*}{9.97} \\
\hline & & Medium contact (13-24) & 17 & 22.7 & & \\
\hline & & High contact $(>24)$ & 25 & 33.3 & & \\
\hline \multirow{2}{*}{$\begin{array}{r}\text { Organizational } \\
\text { participation }\end{array}$} & \multirow[b]{2}{*}{ Scale } & Low participation (up to 7) & \multirow[b]{2}{*}{30} & & & \\
\hline & & & & 40 & 8.76 & 3.34 \\
\hline
\end{tabular}




\begin{tabular}{|c|c|c|c|c|c|c|}
\hline \multirow{5}{*}{$\begin{array}{c}\text { Selected } \\
\text { characteristics }\end{array}$} & \multirow{5}{*}{$\begin{array}{l}\text { Measuring } \\
\text { unit }\end{array}$} & \multirow[t]{2}{*}{ Categories } & \multicolumn{2}{|c|}{ Respondents } & \multirow[t]{5}{*}{ Mean } & \multirow[t]{5}{*}{ SD } \\
\hline & & & No & $\%$ & & \\
\hline & & $\begin{array}{l}\text { Medium participation }(8-14) \\
(8-14)\end{array}$ & 41 & 54.7 & & \\
\hline & & High participation (> 14) & 4 & 5.3 & & \\
\hline & & Low knowledge (up to 7) & 37 & 49.3 & & \\
\hline \multirow{2}{*}{$\begin{array}{c}\text { Knowledge on } \\
\text { sustainable } \\
\text { use of water } \\
\text { resources }\end{array}$} & & Medium knowledge (8-14) & 14 & 187 & \multirow{2}{*}{10.09} & \multirow{2}{*}{5.61} \\
\hline & & High knowledge (>14) & 24 & 32 & & \\
\hline
\end{tabular}

Note: $\mathrm{SD}=$ Standard Deviation

Data in table 1 revealed that majority of the farmers $(49.3 \%)$ were middle-aged and considerable proportion of the farmers $(36 \%)$ had primary education. The highest proportion of the farm size was small (54\%). Majority of the farmers (57.3\%) had low annual family income and short duration training experience $(45.3 \%)$ while the significant proportion of farmers had low extension media contact (44\%), medium organizational participation $(54.7 \%)$ and highest proportion of farmers had low knowledge on sustainable use of water resources (49.3\%).

\section{Water flow in Teesta river during dry season}

Water flow of Teesta River has been significantly decreasing during the last 15 years. According to the data provided by BWDB, it is in remarkably declining phase. A graphic representation of water flow in Teesta river during last 15years is given below to providing an understand of the water scarcity scenario.

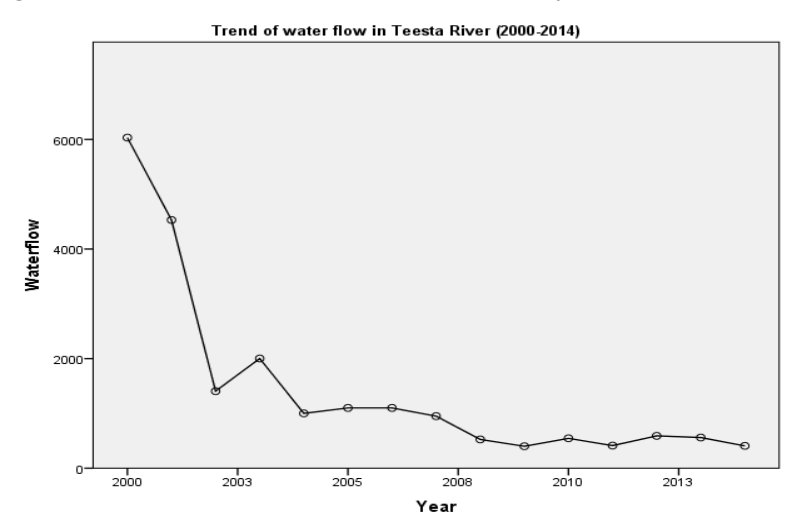

Figure 1. Trend of water flow in Teesta River (2000-2014) (Unreleased data source: BWDB, 2015) 


\section{Changes in Coverage of Major Available Sources of Water for Agricultural Production}

This was measured to know the real coverage by different water sources for agricultural production i.e., irrigation. From the data presented in table 2 revealed that four main sources of water for agricultural productions were available. There is a remarkable change in coverage by deep tube well. Before 2000, no coverage was done by deep tube well because surface water i.e. water from Teesta river was sufficiently available. But now, the coverage has been significantly increasing up to 85.33 percent. The ' $\mathrm{t}$ ' value was 18.106 which is statistically significant at 1.0 percent level. But, this trend is not good for sustainable agriculture. There are plenty of heavy metals like arsenic, lead etc. are being lifted with ground water and the level is continually falling.

Table 2. Distribution of coverage of major available sources of water for agricultural production

\begin{tabular}{|c|c|c|c|c|c|c|c|c|c|c|}
\hline \multirow{3}{*}{$S$} & \multicolumn{8}{|c|}{ Extent of irrigation coverage } & \multirow{3}{*}{$\begin{array}{c}\text { 't' } \\
\text { value }\end{array}$} & \multirow{3}{*}{$\begin{array}{c}\text { Significance } \\
\text { level }\end{array}$} \\
\hline & \multicolumn{4}{|c|}{ Before 2000} & \multicolumn{4}{|c|}{ At present (in 2014) } & & \\
\hline & $\mathrm{H}$ & $M$ & TSE & NAA & $\mathrm{H}$ & $\mathrm{M}$ & TSE & NAA & & \\
\hline TRW & $\begin{array}{c}70 \\
(93.3)\end{array}$ & $\begin{array}{c}5 \\
(6.6)\end{array}$ & $\begin{array}{c}0 \\
(0.0)\end{array}$ & $\begin{array}{c}0 \\
(0.0)\end{array}$ & $\begin{array}{c}3 \\
(4.0)\end{array}$ & $\begin{array}{c}15 \\
(20)\end{array}$ & $\begin{array}{c}38 \\
(50.6)\end{array}$ & $\begin{array}{c}19 \\
(25.3)\end{array}$ & -22.36 & .000 \\
\hline STW & $\begin{array}{c}16 \\
(21.3)\end{array}$ & $\begin{array}{c}15 \\
(20)\end{array}$ & $\begin{array}{c}25 \\
(33.3)\end{array}$ & $\begin{array}{c}19 \\
(25.3)\end{array}$ & $\begin{array}{c}12 \\
(16.0)\end{array}$ & $\begin{array}{c}10 \\
(13.3)\end{array}$ & $\begin{array}{c}17 \\
(22.6)\end{array}$ & $\begin{array}{c}36 \\
(48.0)\end{array}$ & -6.08 & .000 \\
\hline DTW & $\begin{array}{c}0 \\
(0.0)\end{array}$ & $\begin{array}{c}33 \\
(44)\end{array}$ & $\begin{array}{c}10 \\
(13.3)\end{array}$ & $\begin{array}{c}32 \\
(42.6)\end{array}$ & $\begin{array}{c}64 \\
(85.3)\end{array}$ & $\begin{array}{c}7 \\
(9.3)\end{array}$ & $\begin{array}{c}4 \\
(5.3)\end{array}$ & $\begin{array}{c}0 \\
(0.0)\end{array}$ & 18.01 & .000 \\
\hline RW & $\begin{array}{c}73 \\
(97.3)\end{array}$ & $\begin{array}{c}2 \\
(2.6)\end{array}$ & $\begin{array}{c}0 \\
(0.0)\end{array}$ & $\begin{array}{c}0 \\
(0.0)\end{array}$ & $\begin{array}{c}33 \\
(44.0)\end{array}$ & $\begin{array}{c}37 \\
(49.3)\end{array}$ & $\begin{array}{c}5 \\
(6.6)\end{array}$ & $\begin{array}{c}0 \\
(0.0)\end{array}$ & -9.12 & .000 \\
\hline
\end{tabular}

Notes: i) Figures in the parenthesis showing the percentage of respondents ii) $\mathrm{S}=$ Source, H=High, $\mathrm{M}=$ Moderate, TSE $=$ To some extent, NAA=Not at all, TRW= Teesta River Water, $\mathrm{STW}=$ Shallow Tube Well, DTW= Deep Tube Well, and RW= Rain Water

\section{Changes in Crop Choices due to Water Shortage}

This was measured by the changes in cropping pattern and crop choices against existing three cropping seasons namely, Rabi, Kharif-1 and Kharif-2 due to water scarcity. 


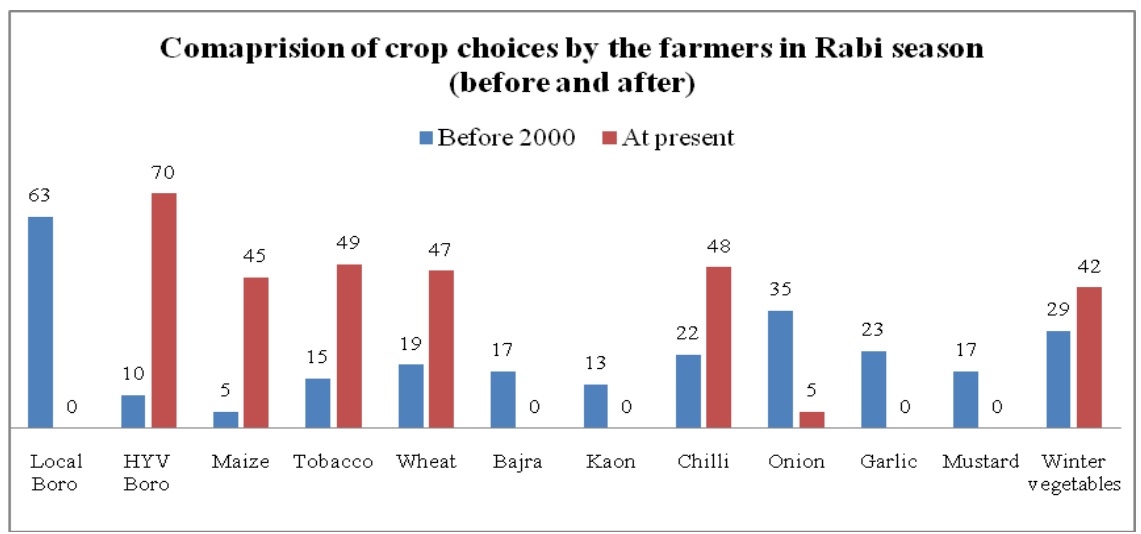

Figure 2. Distribution of crop choices by the farmers in Rabi season (before 2000 and at present)

A great varietal change has been occurred. Before 2000, only China dhan as local Boro was cultivated. In case of HYV Boro, only BR-14 or Gazi dhan was cultivated by farmers but now BRRI dhan-28, BRRI dhan-29, BRRI dhan-33, BRRI dhan-50, Hybrid ACI, Sonar Bangla etc. are being cultivated by farmers. A remarkable change has also been occurred in maize cultivation. Maize is a low water requiring crop and farmers are cultivating maize more than the previous time. The numbers of farmers were only 5 before 2000 , whereas it is now 45 . There is a problem of continuous maize cultivation on the same land. Because, maize is a nutrient exhaustive crop, it uptakes much more nutrient from soil. Thus, decrease soil fertility if it continues more than 2 years at a stretch. Most of the farmers are not concerned or indifferent about this. A great change also occurred in tobacco cultivation because of water shortage. The farmers are compelled to cultivate this crop because profit is high compared to rice and water requirement is also less compared to rice cultivation. Before 2000, 15 farmers had cultivated tobacco, but now almost all farmers i.e. 49 farmers are cultivating tobacco without considering its ecological impact or health hazards. Wheat cultivation is also significantly increasing because of the same reason mentioned in case of other two crops earlier. Only 19 farmers had cultivated wheat before 2000, but now 47 farmers are cultivating wheat. 


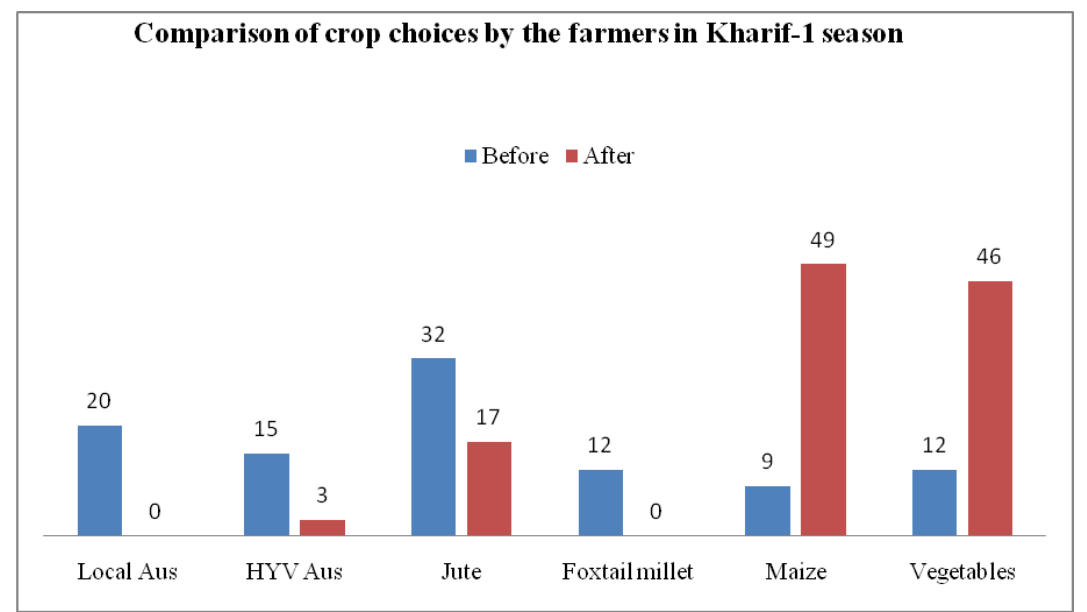

Figure 3. Distribution of crop choices by the farmers in Kharif-1 season (before 2000 and at present)

There is remarkable changes occur in maize and vegetables cultivation. 49 and 46 farmers are cultivating maize and vegetables compared to 9 and 12 farmers before 2000. This is due to water scarcity also remains in Kharif-1 season and farmers are shifting their cultivation pattern. Kachu, spinach etc. vegetables are now generally cultivated in Kharif-1 season.

\section{Changes in Irrigation Costs of Major Crops due to Water Shortage}

Table 4 depicts that before 2000, the average cost of irrigation in case of Boro rice was only Tk. 4352.00 per hectare whereas the average cost is now Tk. 25092.66. The ' $\mathrm{T}$ ' value was 178.408 and it was significant at 1.0 percent level. We know, Boro rice is a high water requiring crop and irrigation cost is vital for the crop production. During FGDs, the farmers opined that they are producing Boro rice with very less coverage considering no profit due to severe increase of cost of irrigation.

Table 3. Changes in irrigation costs of major crops (Source: Field data)

\begin{tabular}{c|c|c|c|c|c}
\hline $\begin{array}{c}\text { Sl. } \\
\text { No. }\end{array}$ & Crops & $\begin{array}{c}\text { Average cost } \\
\text { before 2000 } \\
\text { in Taka ha }^{-1} \text { ) }\end{array}$ & $\begin{array}{c}\text { Average cost at } \\
\text { present } \\
\text { (in Taka ha }^{-1} \text { ) }\end{array}$ & 'T' value & $\begin{array}{c}\text { Significance } \\
\text { level }\end{array}$ \\
\hline 1 & Boro rice & 4352.00 & 25092.66 & 178.41 & .000 \\
2 & Aman rice & 828.00 & 5873.33 & 30.73 & .000 \\
3 & Wheat & 1434.00 & 5553.33 & 144.75 & .000 \\
4 & Maize & 1568.00 & 6584.00 & 254.21 & .000 \\
5 & Toacco & 1568.00 & 6584.00 & 254.21 & .000 \\
6 & Potato & 1309.33 & 4606.00 & 312.10 & .000 \\
\hline
\end{tabular}


It is now much clear that water scarcity is largely contributing in increasing cost of irrigation in almost all crops. So, the crop cultivation is facing many challenges and farmers are getting less profit from farming. With the water shortage and increasing of irrigation costs, some high lands are remain fallow and that is also causing a threat to crop production and sustainable livelihood of farmers.

\section{Problems Faced by the Farmers in Crop Production Due to Water Shortage}

The data presented in table 4 show that the highest portions of the respondents (58.7 percent) have faced medium constraints in crop production, while 40.0 percent of the respondents faced high constraints and only 1.3 percent faced low constraints. This means that the large portion (98.7 percent) of the farmers have faced medium to high problems in crop production mainly because of shortage of water for irrigation,

Table 4. Distribution of the farmers according to the problems faced by them

\begin{tabular}{l|c|c|c|c}
\hline \multicolumn{1}{c|}{ Category } & No & Percent & Mean & Standard deviation \\
\hline Low problems (up to 10) & 1 & 1.3 & \\
Medium problems (11-20) & 44 & 58.7 & \multirow{2}{*}{19.04} & 4.24 \\
High problems (above 20) & 30 & 40.0 & & \\
Total & 75 & 100.0 & & \\
\hline
\end{tabular}

For having a better understanding regarding farmers' problems in crop production it was necessary to have an idea about the comparative problem facing in 10 selected problems. The computed PFI of the 10 problems ranged from 98 to 225 (against a possible range from 0 to 225) which are arranged in rank order according to their PFI as shown in table 5.

Table 5. Rank order of problems faced by the farmers in crop production due to water shortage

\begin{tabular}{c|l|c|c|c|c|c|c}
\hline \multirow{2}{*}{$\begin{array}{c}\text { Sl. } \\
\text { No. }\end{array}$} & \multicolumn{1}{|c|}{ Name of the problems } & \multicolumn{4}{|c|}{ Extent of problems } & PFI & $\begin{array}{c}\text { Rank } \\
\text { order }\end{array}$ \\
\cline { 3 - 6 } & & High & Medium & Low & NAA & & \\
\hline 1 & Irrigation cost increase & 75 & 0 & 0 & 0 & 225 & 1 \\
2 & $\begin{array}{l}\text { Less profit in farming } \\
3\end{array}$ & 72 & 3 & 0 & 0 & 222 & 2 \\
$\begin{array}{l}\text { Heavy metal in crop land } \\
\text { increase }\end{array}$ & 13 & 12 & 41 & 9 & 104 & 9 \\
4 & $\begin{array}{l}\text { Problem in land preparation } \\
\text { on time }\end{array}$ & 22 & 29 & 24 & 0 & 148 & 7 \\
5 & $\begin{array}{l}\text { Problem in intercultural } \\
\text { operation }\end{array}$ & 12 & 17 & 39 & 7 & 109 & 8 \\
6 & $\begin{array}{l}\text { Soil fertility decrease } \\
7\end{array}$ & 52 & 19 & 4 & 0 & 198 & 4 \\
\hline
\end{tabular}




\begin{tabular}{c|c|c|c|c|c|c|c}
\hline \multirow{2}{*}{$\begin{array}{c}\text { S1. } \\
\text { No. }\end{array}$} & Name of the problems & \multicolumn{4}{|c|}{ Extent of problems } & PFI & $\begin{array}{c}\text { Rank } \\
\text { order }\end{array}$ \\
\cline { 3 - 6 } & & High & Medium & Low & NAA & & 10 \\
\hline 8 & $\begin{array}{l}\text { Fallowing of high land and } \\
\text { medium high land }\end{array}$ & 7 & 24 & 29 & 15 & 98 & 10 \\
9 & $\begin{array}{l}\text { Insect infestation and disease } \\
\text { infection }\end{array}$ & 33 & 18 & 24 & 0 & 159 & 6 \\
10 & $\begin{array}{l}\text { Fertilizer and pesticide cost } \\
\text { increase }\end{array}$ & 29 & 43 & 3 & 0 & 176 & 5 \\
\hline
\end{tabular}

N.B. NAA $=$ Not at all

In the study area, it was observed that the farmers are facing different types of problems in crop production and its related practices due to water scarcity. They are always struggling against these unexpected events. It is evident from the table 4.6 that increase in cost of irrigation due to water shortage was the major and most prominent problem for farmers in crop production. All the farmers (100\%) are strongly facing the problem of irrigation cost increase. Due to water shortage, farmers cannot let their land to remain fallow rather they produce crops through irrigation by groundwater. They require more fuel or diesel for uplifting groundwater which is becoming expensive gradually. Again, the second most important problem was less profit in farming. It was directly associated with the first one. Farmers were compelled to irrigate by groundwater using different machines and that is why cost of production increased and farmers could not sell their agricultural produces particularly rice in reasonable price compared to cost of production. They got very low or no profit from rice cultivation. The third important problem arises due to continuous uplifting of groundwater and the decreasing level of underground water. Soil fertility decrease was another important problem which was number 4 problem according to rank order followed by fertilizer and pesticide cost increase (5), insect infestation and disease infection to crops increase (6), problem in land preparation (7), problem in intercultural operation (8), heavy metal in crop land increase (9), and fallowing of high land (10). Increase in insect pest and disease in crops because of water shortage, climate change and global warming. The cost of fertilizer and pesticides are also increasing due to the above mentioned problems. Biodiversity were greatly hampered. Unavailability of water in due time caused problems in land preparation and intercultural operations. As a result, crop productions were also hampered. Water shortage caused problems in irrigation of high lands creating land fallowing problem.

\section{CONCLUSION}

On the basis of findings of the study, their logical interpretation and other relevant facts, we can say that the water flow of Teesta river has been decreasing gradually. Shortage of water was becoming high. Though it was the main source of irrigation water, livelihood, maintaining biodiversity, ecosystem balance. Decrease in the 
overall flow of Teesta river was higher. Due to climate change, upstream diversion of water by neighbouring country etc. water becoming scarce day by day. The cost of irrigation for crop production was found to be drastically increasing in the study area due to water shortage in Teesta river. Thus, benefit-cost ratio was also lowering and the farmers faced serious financial problems as farming was getting less profitable. Farmers faced a number of major and minor problems in crop production due to water shortage in Teesta river basin. Cropping pattern of the study area was significantly changing. Cultivation of low water requiring crops was increasing. Thus, if the present situation continues, it can be concluded that farmers might not be able to produce higher water requiring crops, mainly Boro rice. So, food security may face a great challenge. Knowledge of farmers on sustainable use of water resources were not up to the mark level, so it should be increased in a planned way. It can be concluded clearly that urgent proper sharing of Teesta river water with the neighboring country through proper negotiation and treaty should be accomplished by the government with advocacy from NGOs and other learned persons.

\section{REFERENCES}

BBS. (2011). Statistical Year Book of Bangladesh. 2005, Bangladesh Bureau of Statistics. Ministry of Planning, Government of the People's Republic of Bangladesh, Dhaka.

Haque, A.K., Aich, D., Subhani, R., Bari, E., and Diyan, M.A. (2014). A tale of tamed river: The value of ecosystem services of Teesta river-an estimate of value of provisional services in agriculture and fisheries. Asian Center for Development, Dhaka.

Islam, M.F., and Higano, Y. (2001). Equitable Sharing of Bilateral International Water: a Policy Measure for Optimal Utilization of the Teesta river. Studies in Regional Science, 32 (1), 17-32.

Mullick, M.R.A., Babel1, M.S., and Perret, S.R. (2011). Discharge Based Economic Valuation of Irrigation Water: Evidence from the Teesta River. Bangladesh Journal of Irrigation and Drainage, 60, 481-492.

Rahman, M.M. (2005). Bangladesh-From a Country of Flood to a Country of Water ScarcitySustainable Perspective for Solution. Seminar on Environment and Development, Hamburg, Germany, Entwicklungs Forum Bangladesh. 